AGRICULTURE AND BIOLOGY JOURNAL OF NORTH AMERICA

ISSN Print: 2151-7517, ISSN Online: 2151-7525, doi:10.5251/abjna.2012.3.1.1.5

(C) 2012, ScienceHuß, http://www.scihub.org/ABJNA

\title{
Microbial degradation potential of some Ghanaian soils contaminated with diesel oil
}

\author{
I.YD. Lawson, E.K. Nartey, D.A. Darko, V.A. Okrah and D. Tsatsu \\ Soil Science Department, School of Agriculture, University of Ghana, Box LG \\ 245, Legon-Accra, Ghana, \\ Corresponding author: I.Y.D. Lawson; E-mail: idlawson@ug.edu.gh
}

\begin{abstract}
The experiment was conducted in the laboratory to investigate the degradation of diesel oil in four soils obtained from semi-deciduous forest (Bekwai and Kokofu series) and savanna (Toje and Nyankpala series) zones with the aim to assess the degrading potential of these soils. The soils were contaminated with diesel oil at $10 \mathrm{~g}$ oil $/ \mathrm{kg}$ soil. The contaminated soils were incubated under room temperature and sampled for total aerobic heterotrophic (TAH) bacterial counts, hydrocarbon utilizing bacterial (HUB) populations, and quantity of diesel oil degraded. The TAH bacteria and HUB counts in all the soils increased in response to diesel oil contamination. The TAH bacteria counts in the forest soils took a longer time to reach their peaks than the savanna soils. The cumulative diesel oil degraded gave an upward trend during the period of study. Between 15 and 40 days after incubation the forest soils (Bekwai and Kokofu) degraded more oil than the savanna soils (Toje and Nyankpala). This study revealed that the main factors responsible for differences in degrading abilities of these soils are presence of large populations of hydrocarbon utilizing bacteria, availability of organic carbon, nitrogen and phosphorus. The study also therefore indicated that the Ghanaian soils used in the present investigation have the potential of degrading diesel oil.
\end{abstract}

Key words: Hydrocarbon utilizing bacteria, total aerobic heterotrophic bacteria, diesel oil.

\section{INTRODUCTION}

According to Plohl et al. (2002), petroleum continues to be used as the principal source of energy; however, despite its important usage, petroleum hydrocarbons also pose as a globally environmental pollutant. The whole world, especially the petroleum oil producing countries, are vulnerable to oil spills due to the large volume of petroleum oil and its products transported from producing end to consumer end. For example, in the Niger Delta of Nigeria alone, there have been over 550 reported cases of crude oil spillage since 1976, releasing about 2.8 million barrels of crude oil into the environment (KorieSiakpere, 1998; Odiete, 1999). According to Obayori et al. (2008), petroleum product contamination has been further compounded by sabotage and vandalization of pipelines in restive communities, particularly in the Niger Delta region of Nigeria. In 2010, the oil leak by the British oil giant, British Petroleum or BP, in the Gulf of Mexico in the United States has been described by the environmental experts as the worst in history.
According to Nwaogu (2008), diesel oil is one of the major products of crude oil that constitutes the main source of pollution in the environment. With the increasing demand for diesel oil in cars, trucks, generators and industrial machines, combined with large quantities of the oil being transported over long distances, the contamination of soils through accidental spillage, cleaning of machines and tankers could reach an alarming state. Petroleum products are considered to be recalcitrant to microbial degradation and persist in ecosystems because of their hydrophobic nature and low volatility and thus they pose a significant threat to the environment (Abed et al., 2002). According to Boonchan et al. (2000) and Samanta et al. (2002), the constituents of petroleum such as diesel oil, are carcinogenic, mutagenic and are potent immunotoxicants, thus posing a serious threat to human and animal health. It has been established that, the biodegradation of hydrocarbon-contaminated soils, by exploiting the ability of microbes to degrade and/or detoxify organic contaminants, is an efficient, economic, versatile and environmentally sound treatment (Mehrashi et al., 
2003). Hence, ability of microbes to degrade organic contaminants has formed the basis for bioremediation in the field. However, a number of factors must be considered before in situ bioremediation can be effectively applied. These factors include (i) type and concentration of oil contaminant, (ii) prevalent climatic conditions, (iii) type of environment that has been contaminated, and (iv) nutrient content and (v) $\mathrm{pH}$ of the contaminated site (Rosengerg, 1992).

In 2007 crude oil was discovered in Ghana at Cape Three Point in the Western Region. In the closing days of 2010 when the country joined the league of oil producing countries and when the Jubilee Oil Field officially came on stream with the pumping of oil in commercial quantities, the country had started experiencing oil spillage. On December 26, 2009, the country experienced its first spillage of about 584 barrels of low-based mud drilling fluid and the second mud spill of seven barrels occurred on March 23, 2010 (Ghanaian Daily Graphic, 2010). This frequency of spillage in the drilling field of Cape Three Point is of great concern. Little information is known about the degradation potential of Ghanaian soils regarding petroleum product(s) contamination. The present study therefore investigated the degradation of diesel oil in four soils obtained from different agro-ecological zones in Ghana with the aim to assess the diesel oil degrading potential of these soils as a preliminary research finding in the country to assist in bioremediation of soils contaminated with petroleum product(s) in the future.

\section{MATERIALS AND METHODS}

Soils used: The soils used in this study were Toje series (Ferric Lixisol ), Bekwai series ( Ferric Acrisol), Kokofu series ( Eutric Nitosol), and Nyankpala series (Plinthic Acrisol). The Bekwai and Kokofu series were sampled from the semi-deciduous forest zone, Nyankpala series from the Guinea savanna zone and Toje series from the Coastal savanna zone of Ghana. These soils had no known history of diesel oil or crude oil product(s) contamination. Some of the chemical and biological properties of the soils used are presented in Table 1.

Table 1. Some chemical and biolgocial charateristics of the soils used

\begin{tabular}{|l|l|l|l|l|l|l|}
\hline Soil/characteristics & $\mathrm{pH}(1: 1 \mathrm{H} 2 \mathrm{O})$ & $\begin{array}{l}\text { Organic C } \\
(\mathrm{g} / \mathrm{kg})\end{array}$ & $\begin{array}{l}\text { Nitrogen } \\
(\mathrm{g} / \mathrm{kg})\end{array}$ & $\begin{array}{l}\text { Available P } \\
(\mathrm{mg} / \mathrm{kg})\end{array}$ & TAHB (cfu/g) & HUB (cfu/g) \\
\hline Bekwai & 5.3 & 12.2 & 1.8 & 3.2 & $7.95 \times 10^{6}$ & $5.51 \times 10^{5}$ \\
\hline Kokofu & 5.9 & 13.8 & 2.3 & 4.1 & $9.33 \times 10^{6}$ & $5.49 \times 10^{5}$ \\
\hline Toje & 4.8 & 4.0 & 1.1 & 2.0 & $4.30 \times 10^{6}$ & $3.11 \times 10^{5}$ \\
\hline Nyankpala & 5.7 & 6.4 & 1.1 & 3.3 & $1.12 \times 10^{\prime}$ & $6.9 \times 10^{5}$ \\
\hline
\end{tabular}

Soil sample preparation: The plough layer (0-15 $\mathrm{cm}$ ) of each of the soils was sampled, left in the laboratory at room temperature to condition for $72 \mathrm{~h}$, air dried, sieved (mesh size of $2 \mathrm{~mm}$ ) and contaminated with diesel oil at $10 \mathrm{~g}$ oil $/ \mathrm{kg}$ soil (oven dry basis). The contaminated soils were maintained under same moisture content (10\%; wt:wt basis). The set up was left to stand in the laboratory under room temperature and samples were taken at an interval of 10 days for analysis of heterotrophic and hydrocarbon utilizing bacterial populations and quantity of diesel oil degraded.

Heterotrophic bacterial count: The total aerobic heterotrophic (TAH) bacterial population was estimated using the plate count method with nutrient agar as the growth medium. Ten (10) $\mathrm{g}$ of soil was sampled, tenfold serial dilution prepared; $1 \mathrm{~mL}$ of appropriate dilution was plated onto nutrient agar, and incubated at room temperature for 3 days after which the number of colonies formed was used to estimate the TAH bacterial population.

Hydrocarbon utilizing bacterial population: The hydrocarbon utilizing bacterial count was estimated using the modified mineral salts agar medium of Mills et al. (1978) and modified vapour phase transfer technique of Okpokwasili and Amanchkwu (1988). The serial dilutions $(1 \mathrm{~mL})$ prepared above were plated onto the modified mineral salts medium containing $10 \mathrm{~g} \mathrm{NaCl}, 0.42 \mathrm{~g} \mathrm{MgSO}_{4} .7 \mathrm{H}_{2} \mathrm{O}, 0.29 \mathrm{~g}$ $\mathrm{KCl}, 0.53 \mathrm{~g} \mathrm{KH}_{2} \mathrm{PO}_{4}, 0.42 \mathrm{~g} \mathrm{NH}_{4} \mathrm{NO}_{4}$, and $15 \mathrm{~g}$ agar in $1 \mathrm{~L}$ distilled water (adjusted $\mathrm{pH}=6.8$ ). The modified vapour transfer technique involves spreading $0.5 \mathrm{~mL}$ of diesel (serving as carbon source) onto the mineral salts agar medium after setting and allowed the diesel oil to diffuse into the agar medium for about 1 hr before incubated at room temperature for 5 to 7 days. The number of colonies formed was used to 
estimate the hydrocarbon utilizing bacterial population.

Diesel oil degradation studies: Residual diesel oil in the contaminated soils was extracted using a modified method of Abu and Ogiji (1996). Soil samples were air dried to constant weights and $5 \mathrm{~g}$ were placed into small plastic containers and $10 \mathrm{~mL}$ chloroform was added. Residual oil was extracted by gently shaking the flasks for $5 \mathrm{~min}$. Each extract was filtered through cotton wool in a funnel and collected in a clean glass container, closed immediately and analyzed for diesel oil content. Quantitative determination of diesel oil extracts was employed as described by Udeme and Antai (1988). A standard curve of absorbance $(520 \mathrm{~nm})$ against varying concentrations of diesel oil in chloroform was drawn after taking readings from a spectrophotometer. The diesel oil concentrations were calculated from the standard curve.

\section{RESULTS AND DISCUSSION}

The unavailability of information or data on contaminated soils such as soil conditions, microbial dynamics, and other factors required for optimal degradation of petroleum and its products could delay or hamper the remediation of contaminated sites. The present study reported would provide preliminary information in developing bioremediation strategy for contaminated soils in a developing country like Ghana that has started producing petroleum oil on commercial basis.

Results have shown that the total aerobic heterotrophic (TAH) bacteria in the soils used at the start of the experiment were $4.30 \times 10^{6}(\log 6.63)$, $9.33 \times 10^{6}(\log 7.41), 1.12 \times 10^{7}(\log 7.05)$ and $7.95 \times$ $10^{6}(\log 6.9) \mathrm{cfu} / \mathrm{g}$ with respect to Toje, Kokofu, Nyankpala and Bekwai series (Table 1 and Fig. 1). This indicates that the initial $\mathrm{TAH}$ bacteria in the Nyankpala series were higher than the other soils used. Ten (10) days after incubation (DAI), the TAH bacteria in all the soils increased in response to diesel oil contamination. The Nyankpala series played a leading role in the TAH bacteria at $10 \mathrm{DAI}$ followed by Kokofu series; however, the bacterial count in Toje series overtook that of Bekwai series. The TAH bacterial count in the contaminated soils continued increasing and reached different peaks at or after approximately 15 DAI. Nyankpala and Toje reached their peaks at approximately $15 \mathrm{DAl}$, whiles Kokofu and Bekwai reached their peaks at 30 and 20 DAI, respectively. Thus, the forests soils (Kokofu and Bekwai series) took a longer time to reach their peaks than the savanna soils (Toje and Nyankpala series). This could be attributed to difference in organic carbon in the soils. Analysis has shown that the forest soils contained more organic carbon than the savanna soils (Table 1). The comparable high organic carbon in the forest soils might have served as an additional carbon source apart from the carbon present in the diesel oil and thereby sustaining the heterotrophic bacteria longer than those present in the savanna soils.

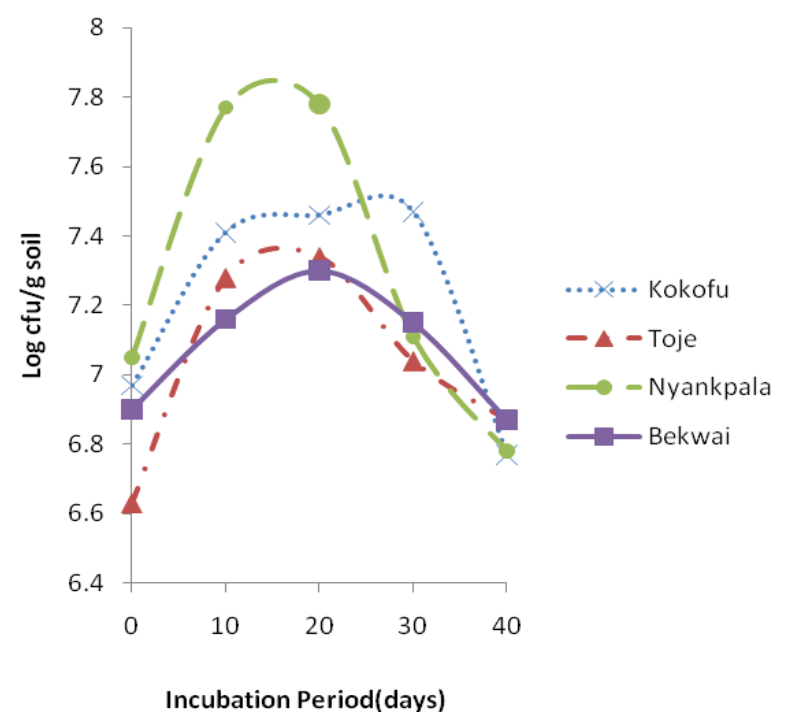

Fig. 1. Heterotrophic bacterial population in the contaminated so

The TAH bacteria in the contaminated soils declined to values of $7.4 \times 10^{6}(\log 6.87), 5.93 \times 10^{6}(\log 6.77)$, $6.07 \times 10^{6}(\log 6.78)$ and $7.4 \times 10^{6}(\log 6.78)$ in Toje, Kokofu, Nyankpala and Bekwai, respectively at 40 DAl; values which were not significantly $(p>0.05)$ different. However, except for Nyankpala series, which was significantly $(p<0.05)$ lower than the initial population, at $40 \mathrm{DAl}$ the other treatments were not significantly $(p>0.05)$ different from their initial populations. The rapid increase in $\mathrm{TAH}$ bacteria immediately after contamination could be attributed to availability of carbon source from the diesel oil.

The growth of hydrocarbon utilizing (HUB) bacteria in the contaminated soils is presented in Fig. 2. The initial HUB populations in Toje, Kokofu, Nyankpala and Bekwai were $3.11 \times 10^{5}, 5.49 \times 10^{5}, 6.69 \times 10^{5}$ and $5.51 \times 10^{5} \mathrm{cfu} / \mathrm{g}$, respectively; which represented percentage values of $7.23,5.88,5.97$ and $6.93 \%$, respectively, based on the initial TAH bacterial count. Ten (10) DAl, there was a sharp increase in HUB populations in all the contaminated soils. There was a 
slight increase in HUB population at 20 DAl and at this time the populations in the Nyankpala soil reached its peak and declined. The other soils continued to increase in HUB populations, however, at 30 DAI Bekwai and Toje reached their peak values of $4.02 \times 10^{7}$ and $8.83 \times 10^{6} \mathrm{cfu} / \mathrm{g}$, respectively. The two soils (Bekwai and Toje) indicated a sharp decrease in HUB populations, reaching values of $7.17 \times 10^{6}$ and $6.02 \times 10^{6}$, respectively, at 40 DAl. The HUB populations in Kokofu soil continued to increase to a value of $6.62 \times 10^{6} \mathrm{cfu} / \mathrm{g}$. At $40 \mathrm{DAl}$, the HUB populations in all the soils were statistically $(p<$ $0.05)$ higher than their initial values. At $40 \mathrm{DAl}$ also, the percentage HUB populations were $81.35,94.77$, 38.39 and $96.89 \%$ with respect to Toje, Kokofu, Nyankpala and Bekwai. It therefore implies that most of the bacterial populations in the Nyankpala soil were non-hydrocarbon bacteria whiles most of the bacteria in Bekwai, Kokofu and Toje were hydrocarbon utilizing bacteria at 40 DAl. Overall result showed that there was increase in hydrocarbon utilizing bacteria in all the contaminated soils. The results are in agreement with Baker (1989), Lee and Levy (1991), Fought and Westlake (1992), Abu and Ogiji (1996) who reported that microbes with ability to degrade crude oil components respond quite rapidly to the presence of petroleum.

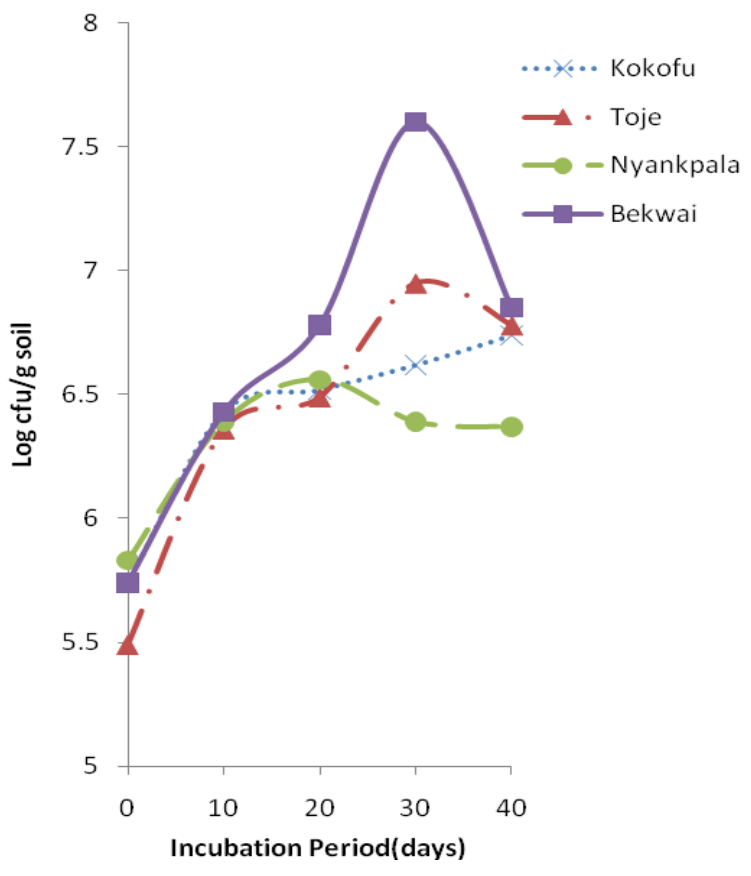

Fig. 2. Hydrocarbon utilizing bacterial population in the contaminated soils
The results obtained on the amount of diesel oil degraded in the soils are shown in Fig. 3. The cumulative diesel oil degraded gave an upward trend during the period of study. Ten (10) DAI, the Bekwai and Nyankpala soils tended to degrade the oil faster than the Kokofu and Toje soils. However, between 15 and 40 DAl the forest soils (Bekwai and Kokofu) degraded more diesel oil than the savanna soils (Toje and Nyankpala). Overall results revealed that the degradation was in the order of Bekwai $>$ Kokofu > Toje > Nyankpala. According to Aichberger et al. (2005), the important aspects necessary in bioremediation studies are microbial composition, contaminant type, geology of polluted site and chemical conditions at the contaminated site. The key factor contributing to low degradation of Nyankpala soil based on the microbial populations, could be due to low hydrocarbon utilizing bacterial numbers.

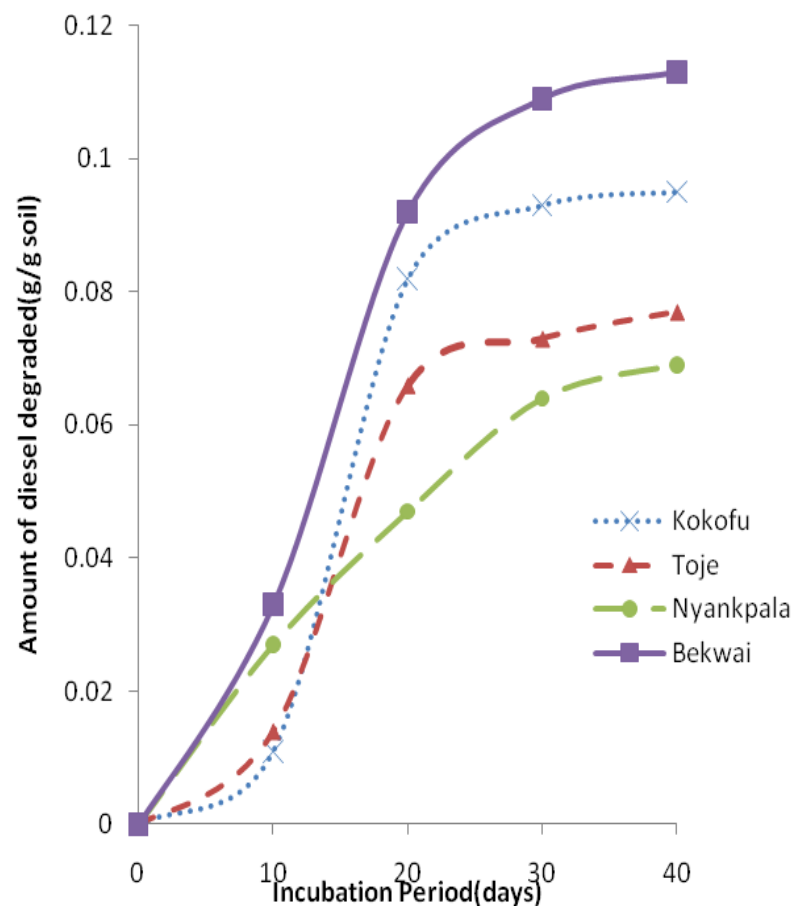

Fig. 3. Amount of diesel oil degraded in the contaminated soils

Even though Toje soil tended to exhibit higher number of hydrocarbon utilizing bacteria than Kokofu soil, the later degraded the contaminant more than the former. The possible factor responsible for this could be the difference in organic carbon, nitrogen and phosphorus contents of these two soils (Table 1). According to Okoh and Trejo-Hernandez (2006), for effective bioremediation one of the requirements 
necessary is the availability of nutrients (nitrogen and phosphorus are essential) to support the microbial growth and enzyme production. Therefore, the major factor contributing to higher degradation in Kokofu than Toje could be differences in organic carbon, nitrogen and phosphorus contents. Apart from these nutrients the added advantage that the Bekwai soil had over the other soils was the high number of hydrocarbon utilizing bacteria.

This study revealed that the main factors responsible for differences in degrading abilities of the soils used are presence of hydrocarbon utilizing bacteria, availability of organic carbon, nitrogen and phosphorus. The study also therefore indicated that the Ghanaian soils used have the potential of degrading diesel oil; however, the forest soils degraded more diesel oil than the savanna soils.

Conclusion: In conclusion, the Ghanaian soils used in the present investigation have the potential of degrading diesel oil. The forest soils used degraded more diesel oil than the savanna soil, and the contributing factors could be differences in hydrocarbon degrading bacteria, organic carbon, nitrogen, and phosphorus contents in the soils.

\section{REFERENCES}

Abed M.M.R, Safi N.M.D, Koster J, deBeer D, El-Nahhal Y, Rullkotter J, Garci-Pichel F. (20020. Microbial diversity of a heavily polluted microbial mat and its community changes following degradation of petroleum compounds. Appl. Environ. Microbiol. 68(4):16741683.

Abu G.O, Ogiji P.A (1996). Initial test of a bioremediation scheme for the clean up of an oil polluted water body in a rural community in Nigeria. Bioresource Technol. 58:7-12

Aichberger H, Hasinger M, Braun R, Loibner A.P (2000). Potential of preliminary test methods to predict biodegradation performance of petroleum hydrocarbons in soil. Biodegr. 16(1):115-125.

Baker J.M (1989). Bioremediation and Ecological rehabilitation following oil spill: paper presented in a seminar organized by Alba Nigeria Limited, Port Harcourt. Nigeria.

Boochan S, Britz M.L, Stanley G.A (2000). Degradation and mineralization of high-molecular weight polycyclic aromatic hydrocarbons by defined fungal-baterial cocultures. Apply. Environ. Microbiol. 66(3):10.

Fought J.M, Westlake D.W (1992). Bioremediation of oil spills. Spill Technical Newsletter 17:3.
Ghanaian Daily Graphic (2010). Low toxicity oil-based mud drilling fluid discharge. Wed, $19^{\text {th }}$ May, 2010. P 1-3

Kori-Siakpere O (1998). Petroleum Induced Alteration in the African Catfish(Clarias gariepinus. Niger. J. Sci. Environ. 5:49-55.

Lee K, Levy E.M (1991). Bioremediation: Waxy crude oil stranded on low energy shorelines. In: proceedings of the 1991 Oil Spill conference, America Petroleum Institute, Washington, D.C.

Mehrashi M.R, Haghighi B, Shariat M, Naseri S, Naddafi K. (2003). Biodegradation of petroleum hydrocarbons in soil. Iranian J. Public Health. 32(3):28-32.

Mills A.L, Breuil C, Colwell R.R (1978). Enumeration of petroleum degrading marine and estuarine microorganisms by the most probable method. Can. J. Microbiol. 24:552-557.

Nwaogu L.A, Onyeze G.O.C, Nwabueze R.N (2008). Degradation of diesel oil in a polluted soil using Bacillus sbtilis. African J. Biotechnol. 7(12):1939-1943.

Obayori O.S, Ilori M.O, Adebusoye S.A, Amund O.O, Oyetibo G.O. (2008). Microbial population changes in tropical agricultural soil experimentally contaminated with crude petroleum. African J. Biotechnol. 7(24):4512-4520.

Odiete W.O (1999). Environmental Physiology and Animals and Pollution. Diversified Resources Ltd. Lagos, Nigeria.

Okoh A. I, Trejo-Hernandez M.R (2006). Remediation of petroleum hydrocarbon polluted systems: Exploiting the bioremediation strategies. African J. Biotechnol 5(25):2520-2525.

Okpokwasili G.C, Amanchkwu S.C (1988). Petroleum hydrocarbon degradation by Candida species. Environ. Int. 14:234-247.

Plohl K, Leskovsek H, Bricelj M (2002). Biological degradation of motor oil in water. Acta Chim. Slovencia.49:279-289.

Rosenberg E (1992). The hydrocarbon-oxidizing bacteria. In Balows A, Truper H.G, Dworkin M, Schleifer K.H (ed.). The prokaryotes: A handbook on the biology of bacteria: Ecophysiology, isolation, identification, applications. Springer Verlag, Heidelberg, Germany.

Samanta K.S. Singh O.V, Jain R.K (2002). Polycyclic aromatic hydrocarbons: Environmental pollution and bioremediation. Trends Biotechnol., 20(6):243-248.

Udeme J, Antai S.P (1988). Biodegradation and mineralization of crude oil bacteria. Nig. J. Biotechnol. 5:79. 